\title{
Air pollution and the respiratory system*
}

\author{
A poluição do ar e o sistema respiratório \\ Marcos Abdo Arbex, Ubiratan de Paula Santos, \\ Lourdes Conceição Martins, Paulo Hilário Nascimento Saldiva, \\ Luiz Alberto Amador Pereira, Alfésio Luis Ferreira Braga
}

\begin{abstract}
Over the past 250 years-since the Industrial Revolution accelerated the process of pollutant emission, which, until then, had been limited to the domestic use of fuels (mineral and vegetal) and intermittent volcanic emissions-air pollution has been present in various scenarios. Today, approximately 50\% of the people in the world live in cities and urban areas and are exposed to progressively higher levels of air pollutants. This is a non-systematic review on the different types and sources of air pollutants, as well as on the respiratory effects attributed to exposure to such contaminants. Aggravation of the symptoms of disease, together with increases in the demand for emergency treatment, the number of hospitalizations, and the number of deaths, can be attributed to particulate and gaseous pollutants, emitted by various sources. Chronic exposure to air pollutants not only causes decompensation of pre-existing diseases but also increases the number of new cases of asthma, COPD, and lung cancer, even in rural areas. Air pollutants now rival tobacco smoke as the leading risk factor for these diseases. We hope that we can impress upon pulmonologists and clinicians the relevance of investigating exposure to air pollutants and of recognizing this as a risk factor that should be taken into account in the adoption of best practices for the control of the acute decompensation of respiratory diseases and for maintenance treatment between exacerbations.
\end{abstract}

Keywords: Respiratory System; Air pollution; Pregnancy; Pulmonary disease, chronic obstructive; Asthma; Respiratory tract Infections.

\section{Resumo}

A poluição atmosférica encontra-se presente nos mais diferentes cenários ao longo dos últimos 250 anos, desde que a Revolução Industrial acelerou o processo de emissão de poluentes que, até então, estava limitado ao uso doméstico de combustíveis vegetais e minerais e às emissões vulcânicas intermitentes. Hoje, aproximadamente 50\% da população do planeta vivem em cidades e aglomerados urbanos e estão expostas a níveis progressivamente maiores de poluentes do ar. Este estudo é uma revisão não sistemática sobre os diferentes tipos e fontes de poluentes do ar e os efeitos respiratórios atribuídos à exposição a esses contaminantes. Podem ser creditados aos poluentes particulados e gasosos, emitidos por diferentes fontes, aumentos nos sintomas de doenças, na procura por atendimentos em serviços de emergência e no número de internações e de óbitos. Mais do que descompensar doenças pré-existentes, exposições crônicas têm ajudado a aumentar o número de casos novos de asma, de DPOC e de câncer de pulmão, tanto em áreas urbanas quanto em áreas rurais, fazendo com que os poluentes atmosféricos rivalizem com a fumaça do tabaco pelo papel de principal fator de risco para estas doenças. Na rotina de clínicos e pneumologistas, esperamos contribuir para consolidar a importância da investigação sobre a exposição aos poluentes do ar e o reconhecimento de que esse fator de risco merece ser levado em conta na adoção da melhor terapêutica para o controle das descompensações agudas das doenças respiratórias e para a sua manutenção entre as crises.

Descritores: Sistema respiratório; Poluição do ar; Gravidez; Doença pulmonar obstrutiva crônica; Asma; Infecções respiratórias.

\footnotetext{
* Study carried out at the Center for Environmental Epidemiology Studies, Air Pollution Laboratory, Department of Pathology, University of São Paulo School of Medicine, São Paulo, Brazil.

Correspondence to: Marcos Abdo Arbex. Rua Dr. Arnaldo, 455, sala 1304, CEP 01246-903, São Paulo, SP, Brasil.

Tel. 5511 3061-8530 or 5516 9714-2882. Email: arbexma@techs.com.br

Financial support: None.

Submitted: 23 July 2012. Accepted, after review: 22 August 2012.
} 


\section{Introduction}

Although the effects of pollution had been described since antiquity, pollution began to have a major impact on the population with the advent of the Industrial Revolution. The rapid urbanization seen worldwide brought about a large increase in energy consumption and in pollutant emissions from stationary fossil fuel burning sources, such as industries, and from mobile sources, such as motor vehicles. Currently, approximately 50\% of the people in the world live in cities and urban areas and are exposed to progressively higher levels of air pollutants. ${ }^{(1)}$ The other half, especially in developing countries, uses solid fuels derived from biomass (wood, charcoal, dried animal dung, and agricultural residues) and, to a lesser extent, liquid fuels, as a source of energy for cooking, heating, and lighting. ${ }^{(1,2)}$

Because of the large contact area between the surface of the respiratory system and the environment, air quality directly affects respiratory health. In addition, a significant quantity of inhaled pollutants reach the systemic circulation through the lungs and can cause deleterious effects on various organs and systems. ${ }^{(3)}$

Global estimates suggest that external environmental pollution (outdoor pollution) causes 1.15 million deaths worldwide (corresponding to nearly $2 \%$ of the total number of deaths) and is responsible for 8.75 million disability-adjusted life years, ${ }^{(4)}$ whereas pollution inside homes causes approximately 2 million premature deaths and results in 41 million disability-adjusted life years. (5) For Brazil, the World Health Organization has estimated that air pollution causes nearly 20,000 deaths/year, a value that is five times as high as the estimated number of deaths from environmental/passive smoking, and that indoor air pollution leads to 10,700 deaths/year. ${ }^{(4,5)}$

\section{Air pollution: sources, site of action, and pathophysiology}

Air pollution is a mixture of particlesparticulate matter (PM)-and gases released into the atmosphere mainly by industries, motor vehicles, and thermoelectric power plants, as well as from biomass and fossil fuel burning. Pollutants can be classified as primary or secondary. Primary pollutants are released directly into the atmosphere, whereas secondary pollutants result from chemical reactions among primary pollutants.

The major primary pollutants monitored by the major environmental agencies in Brazil and worldwide are nitrogen oxides ( $\mathrm{NO}_{2}$ or $\mathrm{NO}_{x}$ ), volatile organic compounds (VOCs), carbon monoxide (CO), and sulfur dioxide ( $\left.\mathrm{SO}_{2}\right)$. One example of a secondary pollutant is ozone $\left(\mathrm{O}_{3}\right)$, formed by the photo-oxidation-induced chemical reaction of VOCs and $\mathrm{NO}_{2}$ in the presence of ultraviolet rays from sunlight. ${ }^{(6,7)}$

The most studied pollutant is PM, which can be primary or secondary. It varies in number, size, shape, surface area, and chemical composition depending on its place of production and its emission source. The deleterious effects of PM on human health depend on PM size and chemical composition. The multiple chemical components of PM include a core of elemental or organic carbon; inorganic compounds, such as sulfates and nitrates; transition metal oxides; soluble salts; organic compounds, such as polycyclic aromatic hydrocarbons; and biological materials, such as pollen, bacteria, spores, and animal remains. On the basis of total suspended particle size, PM is classified as follows: constituent particles of up to $30 \mu \mathrm{m}$ in diameter; constituent particles of less than $10 \mu \mathrm{m}$ in diameter $\left(\mathrm{PM}_{10}\right.$ or inhalable fraction); constituent particles of less than $2.5 \mu \mathrm{m}$ in diameter $\left(\mathrm{PM}_{2.5}\right.$ or fine $\left.\mathrm{PM}\right)$; and constituent particles of less than $10 \mathrm{~nm}$ in diameter $\left(\mathrm{PM}_{0.1}\right.$ or ultrafine PM). ${ }^{(6,7)}$

Chart 1 shows the major pollutants monitored by environmental protection agencies in urban areas, as well as their sources, their sites of action in the respiratory system, and their effects on human health.

\section{How air pollutants affect the respiratory system}

Several mechanisms have been suggested to explain the adverse effects of air pollutants. The most consistent and most widely accepted explanation is that, once in contact with the respiratory epithelium, high concentrations of oxidants and pro-oxidants in environmental pollutants such as PM of various sizes and compositions and in gases such as $\mathrm{O}_{3}$ and nitrogen oxides cause the formation of oxygen and nitrogen free radicals, which in turn induce oxidative stress in the airways. In other words, an increase in free radicals that are not neutralized 
Chart 1 - Major air pollutants, their sources, their sites of action in the respiratory system, and their effects on human health.

\begin{tabular}{|c|c|c|c|}
\hline Pollutants & Source & $\begin{array}{l}\text { Penetration into the } \\
\text { respiratory system }\end{array}$ & Pathophysiology \\
\hline TSP & \multirow{2}{*}{$\begin{array}{l}\text { Anthropogenic sources: street } \\
\text { dust; road dust; agricultural } \\
\text { activities; and construction } \\
\text { activities. Natural sources: sea salt; } \\
\text { pollen; spores; fungi; and volcanic } \\
\text { ash. }\end{array}$} & Nose and throat & \multirow{4}{*}{$\begin{array}{l}\text { It impairs mucociliary and macrophage } \\
\text { activity. It causes airway irritation. } \\
\text { lt induces oxidative stress and, } \\
\text { consequently, pulmonary and systemic } \\
\text { inflammation. Chronic exposure causes } \\
\text { bronchial remodeling and COPD. It can } \\
\text { be carcinogenic. }\end{array}$} \\
\hline $\mathrm{PM}_{10}$ & & $\begin{array}{l}\text { Trachea, bronchi, and } \\
\text { bronchioles }\end{array}$ & \\
\hline $\mathrm{PM}_{2.5}$ & \multirow{2}{*}{$\begin{array}{l}\text { Burning of fossil fuels and } \\
\text { biomass; thermoelectric power } \\
\text { plants }\end{array}$} & Alveoli & \\
\hline $\mathrm{PM}_{0.1}$ & & $\begin{array}{l}\text { Alveoli, lung tissue, } \\
\text { and bloodstream }\end{array}$ & \\
\hline $\mathrm{O}_{3}$ & $\begin{array}{l}\text { It is not emitted directly into } \\
\text { the atmosphere. It is produced } \\
\text { by complex chemical reactions } \\
\text { between volatile organic } \\
\text { compounds (VOCs) and nitrogen } \\
\text { oxides ( } \mathrm{NO}_{\mathrm{x}} \text { ) in the presence of } \\
\text { sunlight. Sunlight and temperature } \\
\text { stimulate such reactions, so } \\
\text { that, on hot sunny days, } \mathrm{O}_{3} \\
\text { concentrations peak. } \\
\text { The sources of VOC and } \mathrm{NO}_{\mathrm{x}} \\
\text { emissions are vehicles, chemical } \\
\text { industries, laundries, and activities } \\
\text { that use solvents. }\end{array}$ & $\begin{array}{l}\text { Trachea, bronchi, } \\
\text { bronchioles, and } \\
\text { alveoli }\end{array}$ & $\begin{array}{l}\text { It is a photochemical oxidant that } \\
\text { is extremely irritating. It induces } \\
\text { respiratory tract mucosal inflammation. } \\
\text { At high concentrations, it irritates } \\
\text { the eyes, the nasal mucosa, and } \\
\text { the oropharynx. It causes cough } \\
\text { and chest discomfort. Exposure for } \\
\text { several hours produces damage to the } \\
\text { epithelium lining the airways. It induces } \\
\text { inflammation and airway obstruction in } \\
\text { the presence of stimuli such as cold and } \\
\text { exercise. }\end{array}$ \\
\hline $\mathrm{NO}_{x}, \mathrm{NO}_{2}$ & $\begin{array}{l}\text { Anthropogenic sources: nitric acid; } \\
\text { sulfuric acid; and combustion } \\
\text { engine industries (major source); } \\
\text { fuel burning at high temperatures, } \\
\text { in thermal power plants that } \\
\text { use gas or incineration. Natural } \\
\text { sources: electrical discharges in the } \\
\text { atmosphere. }\end{array}$ & $\begin{array}{l}\text { Trachea, bronchi, } \\
\text { bronchiole, and } \\
\text { alveoli }\end{array}$ & $\begin{array}{l}\text { An irritant. It affects the mucosa of the } \\
\text { eyes, nose, throat, and lower respiratory } \\
\text { tract. It increases bronchial reactivity } \\
\text { and increases susceptibility to infections } \\
\text { and allergens. It is considered a good } \\
\text { marker of vehicular pollution. }\end{array}$ \\
\hline $\mathrm{SO}_{2}$ & $\begin{array}{l}\text { Anthropogenic sources: petroleum } \\
\text { refineries; diesel vehicles; furnaces; } \\
\text { metallurgy; and papermaking. } \\
\text { Natural sources: volcanic activity. }\end{array}$ & $\begin{array}{l}\text { Upper airways, } \\
\text { trachea, bronchi, and } \\
\text { bronchioles }\end{array}$ & $\begin{array}{l}\text { An irritant. It affects the mucosa of } \\
\text { the eyes, nose, throat, and respiratory } \\
\text { tract. It causes cough and increases } \\
\text { bronchial reactivity, facilitating } \\
\text { bronchoconstriction. }\end{array}$ \\
\hline $\mathrm{CO}$ & $\begin{array}{l}\text { Anthropogenic sources: forest } \\
\text { fires; incomplete combustion } \\
\text { of fossil fuels or other organic } \\
\text { materials; and road transportation. } \\
\text { Urban areas with heavy traffic are } \\
\text { the major contributing source of } \\
\text { CO emissions. } \\
\text { Natural sources: volcanic eruptions } \\
\text { and chlorophyll decomposition. }\end{array}$ & $\begin{array}{l}\text { Alveoli and } \\
\text { bloodstream }\end{array}$ & $\begin{array}{l}\text { lt binds to hemoglobin, interfering } \\
\text { with oxygen transport. It causes } \\
\text { headache, nausea, and dizziness. It } \\
\text { has a deleterious effect on the fetus. } \\
\text { lt is associated with low birth weight } \\
\text { neonates and fetal death. }\end{array}$ \\
\hline
\end{tabular}

TSP: total suspended particles; PM: particulate matter; $\mathrm{PM}_{10}$ : PM of less than $10 \mu \mathrm{m}$ in diameter; $\mathrm{PM}_{2.5}$ : PM of less than $2.5 \mu \mathrm{m}$ in diameter; and $\mathrm{PM}_{0.1}$ : $\mathrm{PM}$ of less than $0.1 \mu \mathrm{m}$ in diameter. Adapted from Kunzli et al ${ }^{(6)}$ 
by antioxidant defenses initiates an inflammatory response with release of inflammatory cells and mediators (cytokines, chemokines, and adhesion molecules) that reach the systemic circulation, leading to subclinical inflammation, which not only has a negative effect on the respiratory system but also causes systemic effects. ${ }^{(6,7)}$

\section{Latency effects}

The effects of pollutants on health can be acute or chronic. Acute effects are manifest shortly after exposure (hours or days). Chronic effects are usually assessed in longitudinal studies over years or decades. ${ }^{(8)}$ Chart 2 summarizes the acute and chronic effects of pollutants on the respiratory system.

\section{Susceptible groups}

\section{Children}

Children are highly susceptible to exposure to air pollutants. Minute ventilation is higher in children than in adults because children have higher basal metabolic rates and engage in more physical activity than do adults, as well as because children spend more time outdoors than do adults. On the basis of body weight, the volume of air passing through the airways of a child at rest is twice that of an adult under similar conditions. Pollutant-induced irritation producing a weak response in adults can result in significant obstruction in children. In addition, the fact that their immune system is not fully developed increases the possibility of respiratory infections. ${ }^{(6,7,9)}$

\section{Elderly individuals}

Elderly individuals are susceptible to the adverse effects of exposure to air pollutants because they have a less efficient immune system (immunosenescence) and a progressive decline in pulmonary function that can lead to airway obstruction and exercise limitation. There is decreased chest wall compliance and lung hyperinflation requiring additional energy expenditure to perform respiratory movements, as well as functional decline of organ systems. ${ }^{(10)}$

\section{Individuals with pre-existing chronic diseases}

The third most susceptible group, regardless of age, comprises individuals with pre-existing chronic diseases affecting mainly the respiratory system (asthma, COPD, and fibrosis) or the circulatory system (arrhythmias, hypertension, and ischemic heart diseases), as well as those with chronic diseases such as diabetes and collagen diseases. ${ }^{(3)}$

\section{Genetic susceptibility}

The production of free radicals and the induction of inflammatory response by pollutants in the respiratory system can be neutralized by the antioxidant agents present in the aqueous layer lining the respiratory epithelium-glutathione S-transferase (GST), superoxide dismutase, catalase, tocopherol, ascorbic acid, and uric acid-which can prevent oxidative stress and represent the first line of defense against the adverse effects of pollutants. ${ }^{(11)}$ Of the antioxidant agents present in the respiratory epithelium, GST is considered the most important ${ }^{(11)}$ and is represented by three major classes of enzymes: GSTM1; GSTP1; and GSTT1. ${ }^{(11)}$

Polymorphisms in genes encoding the enzymes of the GST family can change the expression or function of these enzymes in the lung tissue and result in different responses to inflammation and oxidative stress and, consequently, in increased susceptibility to the adverse effects of air pollutants. ${ }^{(11)}$ Studies conducted in Mexico showed that children with asthma with a deletion polymorphism of genes encoding the GSTM 1 and GSTP1 enzymes had increased susceptibility to $\mathrm{O}_{3}$ exposure, this increased susceptibility being characterized by an increase in biomarkers of nasal inflammation, reduced peak expiratory flow, and increased dyspnea. ${ }^{(12,13)}$

\section{Effects of air pollution during pregnancy}

Exposure to air pollutants during pregnancy can impair fetal development and cause intrauterine growth retardation, prematurity, low birth weight, congenital anomalies, and, in cases that are more severe, intrauterine or perinatal death. ${ }^{(14)}$

The biological mechanisms underlying the effects of air pollutants during pregnancy have yet to be fully elucidated. Extensive cell 
Chart 2 - Acute and chronic effects of pollutants on the respiratory system.

\begin{tabular}{|c|}
\hline Effects of acute exposure (hours and days after increasing pollution) \\
Increased mortality \\
Symptom exacerbation in individuals with COPD or asthma \\
Increased mortality from respiratory diseases \\
Higher frequency of acute respiratory infections \\
Increased number of hospitalizations for pneumonia \\
Increased prevalence of symptoms and signs of eye, nose, and throat irritation \\
Increased prevalence of acute respiratory symptoms (wheezing, cough, and expectoration) \\
Need for increasing the dose of medication \\
Acute changes in pulmonary function \\
Increased number of medical visits, emergency room visits, and hospitalizations \\
Higher rates of work and school absenteeism \\
\hline Effects of chronic exposure (years of chronic exposure) \\
Increased mortality from respiratory diseases \\
Increased incidence and prevalence of asthma and COPD \\
Increased incidence of and mortality from lung cancer \\
Increased incidence of and mortality from pneumonia and influenza \\
Chronic changes in pulmonary function \\
Chronic reduction in FEV and FVC \\
Impaired lung development in children and youths \\
Increased prevalence of below-normal FEV \\
Increased rate of decline in FEV \\
\hline Other effects \\
Low birth weight \\
Preterm delivery \\
\hline Changes in the cognitive development of children \\
\hline
\end{tabular}

Adapted from Kunzli et al. ${ }^{(6)}$

proliferation, physiological immaturity, accelerated organ development, and changes in metabolism increase fetal susceptibility to maternal inhalation of air pollutants, and the maternal respiratory system can, in turn, be compromised by the action of pollutants, thereby affecting placental transport of oxygen and glucose. ${ }^{(15)}$ In addition, pollutants can affect maternal blood coagulation because of an inflammatory response resulting from oxidative stress, increasing the possibility of placental infarction and chronic villitis. ${ }^{(16)}$

A meta-analysis of studies published between 1994 and 2003 revealed that a $10-\mu \mathrm{g} / \mathrm{m}^{3}$ increase in $\mathrm{PM}_{10}$ exposure was associated with a 5\% increase in postnatal mortality from all causes and a $22 \%$ increase in mortality from respiratory diseases. ${ }^{(17)}$ A study conducted in São Paulo, Brazil, revealed that a $1-\mu \mathrm{g} / \mathrm{m}^{3}$ increase in $\mathrm{PM}_{10}$ concentration and a 1-ppm increase in $\mathrm{CO}$ concentration were associated with a $0.6-\mathrm{g}$ and a $12-\mathrm{g}$ reduction in birth weight, respectively. ${ }^{(18)} \mathrm{A}$ study conducted in California, USA, and evaluating 81,186 births found an increased risk of maternal preeclampsia and fetal prematurity associated with higher levels of traffic-generated $\mathrm{NO}_{x}$ and $\mathrm{PM}_{2.5}{ }^{(19)}$

\section{Effects of pollutants on the respiratory system}

\section{Effects on respiratory symptoms}

Epidemiological studies have shown that exposure to gaseous pollutants and PM is associated with a higher incidence of upper airway symptoms, such as rhinorrhea, nasal obstruction, cough, laryngospasm, and vocal fold dysfunction, ${ }^{(20)}$ and lower airway symptoms, such as cough, dyspnea, and wheezing, especially in children. ${ }^{(21)}$ This exposure is also associated with an increase in cough and wheezing in adults with chronic lung disease and in healthy adults. ${ }^{(21)}$

\section{Effects on pulmonary function}

Pulmonary function is an important marker of the effects of air pollution on the exposed 
population, as well as being an early, objective, and quantitative predictor of cardiorespiratory morbidity and mortality. Studies have demonstrated the acute and chronic effects of pollutants on pulmonary function in children, adolescents, healthy adults, and individuals with a history of respiratory disease. ${ }^{(6,7)}$

\section{Effects associated with acute exposure}

Chang et al. ${ }^{(22)}$ investigated the effects of variations in daily concentrations of $\mathrm{PM}_{10}, \mathrm{SO}_{2}$, $\mathrm{CO}$, and $\mathrm{NO}_{2}$ on the pulmonary function of 2,919 students in the 12-16 year age bracket in the city of Taipei, Taiwan. A 1-ppm increase in CO concentration was associated with a $69.8-\mathrm{mL}$ reduction in FVC (95\% Cl: -115.0 to -24.4$)$ and a 73.7-mL reduction in $\mathrm{FEV}_{1}(95 \% \mathrm{Cl}:-118.0$ to -29.7), with a 1-day lag effect. A 1-ppb increase in $\mathrm{SO}_{2}$ concentration was associated with a $12.9-\mathrm{mL}$ reduction in FVC (95\% Cl: -20.7 to -5.1$)$ and an 11.7-mL reduction in $\mathrm{FEV}_{1}(95 \% \mathrm{Cl}:-19.3$ to -4.2), also with a 1-day lag effect. Variations in $\mathrm{O}_{3}$ and $\mathrm{PM}_{10}$ concentrations showed a small but significant negative association with FVC and $\mathrm{FEV}_{1}$ on the day of exposure.

A study conducted in London, England, compared pulmonary function parameters in 60 adults with mild or moderate asthma on two different occasions: after a two-hour walk along 0xford Street, the city's main commercial corridor, where only diesel-powered buses and taxis are allowed; and after a two-hour walk through Hyde Park (a city park). At the time of the study, $\mathrm{PM}_{2.5}$ and $\mathrm{NO}_{2}$ levels were, respectively, 3.0 and 6.5 times higher on 0xford Street than in Hyde Park. There was a $6.1 \%$ reduction in FEV $_{1}(p=0.04)$ and a $5.4 \%$ reduction in FVC $(p=0.001)$ after exposure on 0xford Street in relation to exposure in Hyde Park. ${ }^{(23)}$

\section{Effects associated with chronic exposure}

Gauderman et al. conducted a prospective study following 1,759 children in the 10-18 year age bracket in 12 communities in California, USA, with different levels of $\mathrm{NO}_{2}$, acid vapor, $\mathrm{PM}_{2.5}$, and elemental carbon. After controlling for confounding factors, the authors found that children residing in areas with higher environmental levels of PM showed a significant decline in $\mathrm{FEV}_{1}$ (of approximately $100 \mathrm{~mL}$ ) when compared with those residing in less polluted areas. The effects were significant even in children without bronchial asthma. The proportion of children with an $\mathrm{FEV}_{1}<80 \%$ at age 18 years was five times higher in more polluted communities than in less polluted communities (mean $\mathrm{PM}_{2.5}$ concentrations of $29.0 \mathrm{\mu g} / \mathrm{m}^{3}$ and $6.0 \mathrm{\mu g} / \mathrm{m}^{3}$, respectively). ${ }^{24)}$

Those same authors investigated pulmonary function in 3,677 individuals, who were followed over an 8-year period (between ages 10 and 18 years) and who lived within $500 \mathrm{~m}$ or 1,500 $\mathrm{m}$ of a high-traffic road. At age 18 years, the adolescents living closer to the high-traffic road showed an 81.0-mL deficit in $\mathrm{FEV}_{1}$ and a $127.0-\mathrm{mL} / \mathrm{s}$ deficit in $\mathrm{FEF}_{25-75 \%}$ when compared with those living farther away. ${ }^{(25)}$

A cross-sectional study conducted in Germany evaluated 2,593 women (mean age, 54.5 years) in 7 communities. Levels of $\mathrm{NO}_{2}$ and $\mathrm{PM}_{10}$ showed significant negative associations with $\mathrm{FEV}_{1}, \mathrm{FVC}$, and $\mathrm{FEV}_{1} / \mathrm{FVC}$. An annual increase of $7.0 \mathrm{\mu g} / \mathrm{m}^{3}$ in $\mathrm{PM}_{10}$ was associated with a 5.0\% reduction in $\mathrm{FEV}_{1}$ and a $1.0 \%$ reduction in $\mathrm{FEV}_{1} / \mathrm{FVC}$, and, for an annual increase of $16.0 \%$ in $\mathrm{NO}_{2}$, there was a $4.0 \%$ reduction in $\mathrm{FEV}_{1}$ and a $1.0 \%$ reduction in $\mathrm{FEV}_{1} / \mathrm{FVC}^{(26)}$

A prospective study conducted in Switzerland evaluated 4,742 adults in the 18-60 year age bracket in 8 communities over an 11-year period. Over the study period, there was a mean drop of $5.3 \mu \mathrm{g} / \mathrm{m}^{3}$ in $\mathrm{PM}_{10}$ levels. A $10-\mu \mathrm{g} / \mathrm{m}^{3}$ decline in the mean annual $\mathrm{PM}_{10}$ concentration was associated with statistically significant reductions in the annual rates of decline in $\mathrm{FEV}_{1}$ (of 9\%), $\mathrm{FEF}_{25-75 \%}$ (of 16\%), and $\mathrm{FEV}_{1} / \mathrm{FVC}$ (of 6\%). ${ }^{(27)}$

\section{Pollution and bronchial asthma}

Epidemiological and toxicological studies have demonstrated the association between air pollution and bronchial asthma. ${ }^{(21)}$ Air pollutants are associated with an increase in the number of emergency room visits and hospitalizations for acute asthma attacks, as well as with an increase in expiratory wheezing, respiratory symptoms, and use of rescue medication. ${ }^{(21)}$

The prevalence of bronchial asthma has increased worldwide, especially in highly industrialized urban areas. Prospective studies suggest that exposure to air pollutants can lead to the development of new cases of asthma. One example of this is the large increase in the incidence of asthma in China after the recent 
industrial development and, consequently, the large increase in the concentration of pollutants. ${ }^{(28)}$

\section{Effects associated with acute exposure}

In Athens, Greece, one group of researchers investigated the acute effects of $\mathrm{PM}_{10}$ and $\mathrm{SO}_{2}$ exposure on the number of emergency room visits by children and adolescents in the 0-14 year age bracket between 2001 and 2004. A 10- $\mathrm{\mu g} / \mathrm{m}^{3}$ increase in $\mathrm{PM}_{10}$ and $\mathrm{SO}_{2}$ levels was associated with a $2.2 \%$ increase $(95 \% \mathrm{Cl}: 0.1-5.1)$ and a $6.0 \%$ increase (95\% Cl: 0.9-11.3), respectively, in the number of asthma-related visits. ${ }^{(29)}$

A study involving children and adolescents in the 0-18 year age bracket and conducted in Copenhagen, Denmark, between 2001 and 2008, revealed an increase in the number of asthmarelated hospitalizations due to increased levels of $\mathrm{NO}_{\mathrm{x}}(\mathrm{OR}=1.11 ; 95 \% \mathrm{Cl}: 1.05-1.17), \mathrm{NO}_{2}$ $(\mathrm{OR}=1.10 ; 95 \% \mathrm{Cl}: 1.04-1.16), \mathrm{PM}_{10}(\mathrm{OR}=1.07$ 95\% Cl: 1.03-1.12), and $\mathrm{PM}_{2.5}(\mathrm{OR}=1.09 ; 95 \%$ $\mathrm{Cl}: 1.04-1.13) .{ }^{(30)}$

An association between increased pollutant levels and hospitalizations for asthma has been observed in the city of Araraquara, located in the center of the sugarcane-producing area of the state of São Paulo, Brazil. During the harvest period, when sugarcane straw burning is the largest pollutant emission source, the number of hospitalizations for asthma was 50\% higher than was that during the period when there is no burning $(\mathrm{p}<0.001)$. A $10-\mu \mathrm{g} / \mathrm{m}^{3}$ increase in the concentrations of PM of up to $30 \mu \mathrm{m}$ in diameter was associated with an $11.6 \%$ increase in the number of hospitalizations (95\% Cl: 5.4-17.7), with a 1-day lag effect. ${ }^{(31)}$

A study conducted in the city of Rio Branco, Brazil, showed that, in the forest biomass burning season, the number of asthma-related visits among children under 10 years of age increased in parallel with the increase in $\mathrm{PM}_{2.5}$ concentrations measured in the city. ${ }^{(32)}$

During the Olympic Games in Atlanta, USA, measures to reduce urban pollution were implemented. During the three weeks of games, traffic counts dropped around 22\%. Peak daily levels of $\mathrm{O}_{3}, \mathrm{NO}_{2}, \mathrm{CO}$, and $\mathrm{PM}_{10}$ decreased 28\%, $7 \%, 19 \%$, and $17 \%$, respectively, in comparison with the three weeks before and the three weeks after the Games. There was a $40 \%$ reduction in the number of consultations for asthma among children and an 11-19\% decline in the number of asthma-related visits to the emergency rooms of the city among individuals of all ages. ${ }^{(33)}$ During the Olympic Games in Beijing, $\mathrm{PM}_{2.5}$ and $\mathrm{O}_{3}$ concentrations decreased from $78.8 \mu \mathrm{g} / \mathrm{m}^{3}$ to $46.7 \mu \mathrm{g} / \mathrm{m}^{3}$ and from $65.8 \mathrm{ppb}$ to $61 \mathrm{ppb}$, respectively, and the number of asthma-related emergency rooms visits decreased by $41.6 \%{ }^{.34)}$

\section{Effects associated with chronic exposure}

In a prospective study conducted in 12 communities with different $\mathrm{O}_{3}$ levels in California, USA, 3,535 schoolchildren with no history of asthma were followed over a 5-year period. In the follow-up period, 265 children developed asthma. In communities with high $\mathrm{O}_{3}$ concentrations, the risk of developing asthma was 3.3 times higher $(95 \% \mathrm{Cl}: 1.9-5.8)$ in children who played three or more sports than in those who did not play any sports. In areas with low $\mathrm{O}_{3}$ concentrations, the number of sports played was not a risk factor for the development of asthma. The same was true for time spent outdoors, which was shown to be a direct risk factor for the development of asthma only in areas with high $\mathrm{O}_{3}$ concentrations. ${ }^{(35)}$

Ghering et al. followed the first 8 years of life of 3,863 children in communities in the north, west, and center of the Netherlands. At age 8 years, the children underwent allergy testing and bronchial hyperresponsiveness testing. Levels of $\mathrm{PM}_{2.5}$ were associated with a $28 \%$ increase in the incidence of asthma, a $29 \%$ increase in the prevalence of asthma, and a 15\% increase in asthma symptoms. ${ }^{(36)}$

In Munich, Germany, 2,860 children were followed from birth to age 4 years and 3,061 were followed to age 6 years. The authors categorized residential distance to a main road as follows: < $50 \mathrm{~m} ; 50-250 \mathrm{~m} ; 250-1,000 \mathrm{~m}$; and $>1,000 \mathrm{~m}$. The study showed significant inverse associations between residential distance to a main road and the outcomes analyzed. Among those living less than $50 \mathrm{~m}$ from a main road, the highest ORs were for asthma $(\mathrm{OR}=1.6$; 95\% Cl: 1.03-2.37), hay fever (OR $=1.6 ; 95 \%$ $\mathrm{Cl}: 1.1-2.3)$, and allergic sensitization to pollen $(\mathrm{OR}=1.4 ; 95 \% \mathrm{Cl}: 1.2-1.6)$. $^{(37)}$

A cohort study conducted in Switzerland between 1991 and 2002 and evaluating 2,725 nonsmoking adults in the $18-60$ year age bracket showed that those living in more polluted 
areas were at a higher risk of developing asthma (a 30\% increase in risk for every $1-\mu \mathrm{g} / \mathrm{m}^{3}$ increase in the concentration of traffic-generated $\left.\mathrm{PM}_{10}\right)^{.(38)}$

\section{Pollution and COPD}

Patients with COPD are particularly vulnerable to additional stress on the airways caused by aggressive agents. Smoking is recognized as the most important factor for the development of COPD, especially in developed countries. However, over the last 10 years, an increasing number of studies have suggested that there are risk factors other than smoking in the genesis of COPD. These factors include exposure to indoor and outdoor air pollutants, occupational exposure to dust and fumes, history of recurrent respiratory infections in childhood, history of pulmonary tuberculosis, chronic asthma, intrauterine growth retardation, poor nutrition, and low socioeconomic status. ${ }^{(1)}$

Exposure to air pollution is associated with an increase in respiratory morbidity from COPD, including an increase in respiratory symptoms and a decrease in pulmonary function, as well as being a common cause of exacerbations leading to emergency room visits or hospitalizations. ${ }^{(39)}$ Indoor biomass burning is a significant cause of COPD in nonsmoking women who are exposed to high concentrations of pollutants during cooking activities, especially in rural areas of developing countries, and this significantly contributes to the global increase in the disease. ${ }^{(1,2)}$ While women with COPD caused by smoking have emphysema and goblet cell metaplasia more commonly than do those exposed to biomass burning, the latter group has more severe interlobular septal thickening, more pigment deposition in the lung parenchyma, more small airway fibrosis, and more severe intimal thickening of the pulmonary artery. ${ }^{(39)}$

\section{Effects associated with acute exposure}

An ecological study conducted in Hong Kong, China, investigated the association between air pollutants and hospitalizations for COPD between 2000 and 2004. Significant associations were observed between hospitalizations for COPD and levels of pollutants. The relative risk (RR) of hospitalization for every $10-\mu \mathrm{g} / \mathrm{m}^{3}$ increase in $\mathrm{SO}_{2}, \mathrm{NO}_{2}, \mathrm{O}_{3}, \mathrm{PM}_{10}$, and $\mathrm{PM}_{2.5}$ concentrations was, respectively, 1.007, 1.026, 1.040, 1.024, and 1.031. The effect started on the day of exposure and lasted until the fifth day, as well as being more pronounced in the winter than in the summer. ${ }^{(40)}$

A study conducted between 1986 and 1999 and involving 36 American cities showed that a 5-ppb increase in $\mathrm{O}_{3}$ levels and a $10-\mu \mathrm{g} / \mathrm{m}^{3}$ increase in $\mathrm{PM}_{10}$ levels were associated with an increase of $0.27 \%(95 \% \mathrm{Cl}: 0.1-0.5)$ and $1.5 \%$ (95\% Cl: 0.9-2.0), respectively, in the number of hospitalizations for COPD. Use of central air conditioning was found to reduce the adverse effects of air pollution. ${ }^{(41)}$

A study conducted between 2001 and 2003 in city of São Paulo, Brazil, and evaluating 1,769 patients over 40 years of age showed that an increase in the number of COPD-related emergency room visits was associated with increases in air concentrations of $\mathrm{PM}_{10}$ and $\mathrm{SO}_{2}$. Variations in $\mathrm{PM}_{10}$ and $\mathrm{SO}_{2}$ concentrations $\left(28.2 \mu \mathrm{g} / \mathrm{m}^{3}\right.$ and $7.8 \mu \mathrm{g} / \mathrm{m}^{3}$, respectively) were associated with a cumulative 6-day increase of 19\% and 16\% in COPD admissions, respectively. A $10-\mu \mathrm{g} / \mathrm{m}^{3}$ increase in $\mathrm{PM}_{10}$ concentration was associated with a $6.7 \%$ increase in the number of visits on the day of exposure. ${ }^{(42)}$

\section{Effects of chronic exposure}

Schikowski et al. followed 4,757 women in the 54-55 year age bracket in Germany, using diagnostic criteria for COPD established by the Global Initiative for Chronic Obstructive Lung Disease. The prevalence of COPD (stages 1-IV) was found to be $4.5 \%$. A $7-\mu \mathrm{g} / \mathrm{m}^{3}$ increase in the 5-year mean $\mathrm{PM}_{10}$ concentration was associated with a 1.33 OR $(95 \% \mathrm{Cl}: 1.03-1.72)$ for the development of COPD and a 5.1\% decline in $\mathrm{FEV}_{1}$ (95\% Cl: 2.5-7.7). Women living less that $100 \mathrm{~m}$ from a high-traffic road were at a higher risk of developing COPD than were those living farther away $(\mathrm{OR}=1.8 ; 95 \% \mathrm{Cl}: 1.1-3.0) .{ }^{(26)}$ Those authors suggest that chronic exposure to traffic-generated $\mathrm{PM}_{10}$ increases the risk of developing COPD and accelerates pulmonary function loss.

A study conducted in Denmark followed 57,053 individuals between 1993 and 2004 and showed that 1,786 (3.4\%) developed COPD. The authors found a positive association between COPD and exposure to traffic-generated pollutants after controlling for confounding factors, including smoking. The incidence of COPD was associated with the 35-year $\mathrm{NO}_{2}$ mean 
concentration ( $\mathrm{RR}=1.08 ; 95 \% \mathrm{Cl}: 1.02-1.14$ for an interquartile range of $\left.5.8 \mathrm{\mu g} / \mathrm{m}^{3}\right) .{ }^{(43)}$

A meta-analysis of 15 studies showed that individuals exposed to biomass burning have a 2.4 higher OR (95\% Cl: 1.9-3.3) for the development of COPD than do those who were not exposed. ${ }^{(44)}$ A recent meta-analysis of 25 studies showed that the risk in women exposed to biomass burning is similar to that in women who used another type of fuel $(\mathrm{OR}=2.4 ; 95 \% \mathrm{Cl}: 1.5-9.9){ }^{(2)}$

In a meta-analysis, Kurmi et al. showed a positive association of use of solid fuel with COPD (OR $=2.8 ; 95 \% \mathrm{Cl}: 1.8-4.0)$ and chronic bronchitis $(\mathrm{OR}=2.3 ; 95 \% \mathrm{Cl}: 1.9-2.8)$ when compared with use of other types of fuels. ${ }^{(45)}$ The risk is similar to that reported for smokers who developed COPD (OR $=2.5)$ and is higher than that for individuals who developed COPD because of passive smoking or alpha- 1 antitrypsin deficiency. On the basis of a comparison of the 1.1 billion smokers with the 3 billion individuals exposed to high concentrations of pollutants generated by solid fuel burning, Kodgule \& Salvi hypothesized that the latter exposure is a more significant risk factor for the development of COPD. ${ }^{(46)}$

\section{Pollution and acute respiratory infection}

Acute lower respiratory tract infection is the leading cause of death in children up to 5 years of age. In this age group, this type of infection causes 2 million deaths per year. Half of such deaths are attributed to indoor exposure to pollutants from solid fuel burning. (46) A meta-analysis of 24 studies showed that indoor exposure to biomass burning increases the risk of pneumonia in children (OR $=1.8 ; 95 \%$ $\mathrm{Cl}: 1.5-2.1){ }^{(47)}$ Similarly, a recent meta-analysis of 25 studies found a significant and robust association between indoor biomass burning and acute respiratory infection in children $(\mathrm{OR}=3.5$; 95\% Cl: 1.9-6.4). ${ }^{(2)}$

\section{Effects associated with acute exposure}

Host et al. investigated the association of $\mathrm{PM}_{10}$ and $\mathrm{PM}_{2.5}$ concentrations with hospitalization for respiratory infection in 6 French cities between 2000 and 2003. The excess RR of hospitalization for respiratory infection for every $10-\mu \mathrm{g} / \mathrm{m}^{3}$ increase in $\mathrm{PM}_{10}$ and $\mathrm{PM}_{2.5}$ concentrations was $4.4 \%$
(95\% Cl: 0.9-8.0) and 2.5\% (95\% Cl: 0.1-4.8), respectively. Children under 15 years of age constituted the most susceptible age group. ${ }^{(48)}$

Belleudi et al. investigated the effects of PM on the number of hospitalizations for pneumonia among individuals over 35 years of age admitted to any of five Roman hospitals between 2001 and 2005. A $10-\mu \mathrm{g} / \mathrm{m}^{3}$ increase in $\mathrm{PM}_{2.5}$ concentration was associated with a $2.8 \%$ increase in the number of hospitalizations for pneumonia, with a 2-day lag effect. ${ }^{(49)}$

Medina-Ramón et al., in a study conducted between 1986 and 1999 and involving 36 American cities, showed that, during the hottest period, a cumulative 2-day increase of $5 \mathrm{ppb}$ in $\mathrm{O}_{3}$ concentration was associated with a $0.41 \%$ increase (95\% Cl: 0.26-0.57) in the number of hospitalizations for pneumonia. Similarly, a $10-\mu \mathrm{g} / \mathrm{m}^{3}$ increase in $\mathrm{PM}_{10}$ concentration was associated with a $0.8 \%$ increase in the number of hospitalizations for pneumonia on the day of exposure (95\% Cl: 0.5-1.2). ${ }^{(41)}$

\section{Effects associated with chronic exposure}

Between 2003 and 2005, Neupane et al. conducted a case-control study in Canada in which they investigated long-term exposure to $\mathrm{NO}_{2}, \mathrm{PM}_{2.5}$, and $\mathrm{SO}_{2}$ and the risk of hospitalization for pneumonia in individuals over 65 years of age. They evaluated 365 elderly individuals with radiologically confirmed community-acquired pneumonia and 494 controls. The groups were compared on the basis of individual exposure to $\mathrm{NO}_{2}, \mathrm{PM}_{2.5}$, and $\mathrm{SO}_{2}$ in the previous year. long-term ( $\geq 1$-year) exposure to high levels of $\mathrm{NO}_{2}$ and $\mathrm{PM}_{2.5}$ was significantly associated with hospitalization for community-acquired pneumonia. ${ }^{(50)}$

A cohort study conducted in the USA showed that a $10-\mu \mathrm{g} / \mathrm{m}^{3}$ increase in $\mathrm{PM}_{2.5}$ concentration was associated with a $20 \%$ increase in the risk of death from pneumonia and influenza in nonsmokers. ${ }^{(51)}$

\section{Pollution and lung cancer}

The World Health Organization estimates that, in 2008, there were 12.7 million new cases of cancer that caused 7.6 million deaths worldwide, the number of new cases of lung cancer and the number of deaths from lung 
cancer being 1.61 million and 1.18 million, respectively. ${ }^{(52)}$ Studies have shown the effects of exposure to pollutants and the development of lung cancer, which is attributed to the direct action of carcinogens present in pollution and to the chronic inflammation induced by such carcinogens. ${ }^{(7,53)}$

A prospective study involving 500,000 adults in 50 states in the USA ${ }^{(54)}$ showed that a $14 \%$ increase in the incidence of lung cancer was associated with a $10-\mu \mathrm{g} / \mathrm{m}^{3}$ in $\mathrm{PM}_{2.5}$ concentration. In a study conducted in European countries, 5\% and $7 \%$ of the various types of lung cancer in nonsmokers and former smokers, respectively, were attributed to the effects of pollution. ${ }^{(55)} \mathrm{An}$ analysis of several cohort and case-control studies suggested that, on average, chronic exposure to air pollution increases the risk of lung cancer incidence by $20-30 \% .^{(7,56)}$

\section{Air pollution and mortality}

In a review of studies conducted in various countries and investigating the effects of acute changes in pollution levels, it was suggested that a $0.4-1.3 \%$ increase in the RR of death is associated with a $10-\mu \mathrm{g} / \mathrm{m}^{3}$ increase in $\mathrm{PM}_{2.5}$ levels or a $20-\mu \mathrm{g} / \mathrm{m}^{3}$ increase in $\mathrm{PM}_{10}$ levels. ${ }^{2.57}$ The largest impact on mortality occurs among children under 5 years of age $(R R=1.6 \%)$ and among elderly individuals ( $R R=2.0 \%)$, for every $10-\mu \mathrm{g} / \mathrm{m}^{3}$ increase in $\mathrm{PM}_{10}$ concentration. ${ }^{(57)}$

In the USA, the most relevant studies on the chronic effects of air pollution on mortality have estimated a $6-17 \%$ increase in cardiopulmonary mortality for a $10-\mu \mathrm{g} / \mathrm{m}^{3}$ increase in $\mathrm{PM}_{2.5}$ levels. ${ }^{(57)}$

\section{Effects of air pollution on exercise}

\section{Air pollution and physical exercise - risks and benefits}

During aerobic exercise, the inhaled air enters the airways mostly through the mouth and minute volume and diffusing capacity increase, facilitating the penetration of pollutants. ${ }^{(58)}$ The quantity of ultrafine particles deposited in the respiratory tract is nearly five times higher during moderate exercise than at rest and increases as particle size decreases. ${ }^{(59)}$

Exercising near a high-traffic road increases carboxyhemoglobin levels (a 30-min run can increase carboxyhemoglobin levels to levels equivalent to those resulting from smoking 10 cigarettes/day) and reduces aerobic performance in athletes. ${ }^{(58)}$

Although the major recommendations of sports medicine societies do not include precautions against exercising in polluted environments, a recent statement from the American Heart Association $^{(3)}$ on the effects of pollution recommends that intensive exercise be avoided when air quality is unsatisfactory.

A recent review ${ }^{(60)}$ investigating the effects of pollution on athlete performance concluded that exercising in environments with high levels of pollutants sharply reduces pulmonary and vascular function in individuals with asthma and in healthy individuals, and that long-term exercise in polluted environments is associated with reduced pulmonary function and can induce vascular dysfunction, probably due to systemic and airway oxidative stress, leading to reduced exercise performance. In brief, it is recommended that susceptible individuals (those with asthma, those with COPD, patients with cardiovascular disease, elderly individuals, and children) avoid exercising when air quality is poor.

\section{Final considerations}

Exposure to air pollutants poses a risk to human health as early as in intrauterine life.

Health professionals should recognize the importance of the effects of pollutants in clinical practice and properly assess the exposure profile of patients at home, in the workplace, and in the region of residence. If it is not possible to reduce the emission of pollutants in the short or medium term, it is perfectly possible to counsel patients regarding the adoption of preventive measures to reduce the effects of indoor and outdoor pollutants, reducing the adverse effects associated with this exposure. In addition, physicians should, as appropriate, not only make adjustments to the standard treatment when increases in air pollutant concentrations can aggravate pre-existing diseases but also, as citizens, use their knowledge to promote the adoption of measures to reduce pollutant levels in urban and rural areas.

\section{References}

1. Salvi SS, Barnes PJ. Chronic obstructive pulmonary disease in non-smokers. Lancet. 2009;374(9691):733-43. http:// dx.doi.org/10.1016/S0140-6736(09)61303-9 
2. Po JY, FitzGerald JM, Carlsten C. Respiratory disease associated with solid biomass fuel exposure in rural women and children: systematic review and meta-analysis. Thorax. 2011;66(3):232-9. PMid:21248322. http:// dx.doi.org/10.1136/thx.2010.147884

3. Brook RD, Rajagopalan S, Pope CA 3rd, Brook JR, Bhatnagar A, Diez-Roux AV, et al. Particulate matter air pollution and cardiovascular disease: An update to the scientific statement from the American Heart Association. Circulation. 2010;121(21):2331-78. PMid:20458016. http://dx.doi.org/10.1161/CIR.0b013e3181 dbece1

4. World Health Organization. Global health risks. Mortality and burden of disease attributable to selected major risks. Geneva: World Health Organization; 2009.

5. Oberg M, Jaakkola MS, Woodward A, Peruga A, PrüssUstün A. Worldwide burden of disease from exposure to second-hand smoke: a retrospective analysis of data from 192 countries. Lancet. 2011;377(9760):139-46. http://dx.doi.org/10.1016/S0140-6736(10)61388-8

6. Künzli N, Perez L, Rapp R. Air quality and health. Lausanne: European Respiratory Society; 2010.

7. World Health Organization. Air quality guidelines. Global update 2005. Particulate matter, ozone, nitrogen dioxide and sulfur dioxide. Copenhagen: World Health Organization; 2005. http://dx.doi.org/10.3201/ eid 1110.050644

8. Braga AL, Zanobetti A, Schwartz J. The lag structure between particulate air pollution and respiratory and cardiovascular deaths in 10 US cities. J Occup Environ Med. 2001;43(11):927-33. PMid:11725331. http://dx.doi. org/10.1097/00043764-200111000-00001

9. Salvi S. Health effects of ambient air pollution in children. Paediatr Respir Rev. 2007;8(4):275-80. PMid:18005894. http://dx.doi.org/10.1016/j.prrv.2007.08.008

10. Sharma G, Goodwin J. Effect of aging on respiratory system physiology and immunology. Clin Interv Aging. 2006;1(3):253-60. http://dx.doi.org/10.2147/ ciia.2006.1.3.253

11. Minelli C, Wei l, Sagoo G, Jarvis D, Shaheen S, Burney P. Interactive effects of antioxidant genes and air pollution on respiratory function and airway disease: a HuGE review. Am J Epidemiol. 2011;173(6):603-20. PMid:21343247. http://dx.doi.org/10.1093/aje/kwq403

12. Romieu 1, Sienra-Monge JJ, Ramírez-Aguilar M, MorenoMacías H, Reyes-Ruiz Nl, Estela del Río-Navarro B, et al. Genetic polymorphism of GSTM1 and antioxidant supplementation influence lung function in relation to ozone exposure in asthmatic children in Mexico City. Thorax. 2004;59(1):8-10. PMid:14694237 PMCid:1758856.

13. Romieu I, Ramirez-Aguilar M, Sienra-Monge JJ, MorenoMacías H, del Rio-Navarro BE, David G, et al. GSTM1 and GSTP1 and respiratory health in asthmatic children exposed to ozone. Eur Respir J. 2006;28(5):953-9. PMid:16870661. http://dx.doi.org/10.1183/0903193 6.06.00114905

14. Srám RJ, Binková B, Dejmek J, Bobak M. Ambient air pollution and pregnancy outcomes: a review of the literature. Environ Health Perspect. 2005;113(4):375-82. PMid:15811825 PMCid:1278474. http://dx.doi.org/10.1289/ ehp. 6362

15. Ritz B, Wilhelm M. Ambient air pollution and adverse birth outcomes: methodologic issues in an emerging field. Basic Clin Pharmacol Toxicol. 2008;102(2):182-90. PMid:18226073. http:// dx.doi.org/10.1111/j.1742-7843.2007.00161.x
16. Kannan S, Misra DP, Dvonch JT, Krishnakumar A. Exposures to airborne particulate matter and adverse perinatal outcomes: a biologically plausible mechanistic framework for exploring potential effect modification by nutrition. Environ Health Perspect. 2006;114(11):1636-42. PMid:17107846 PMCid:1665414.

17. Lacasaña M, Esplugues A, Ballester F. Exposure to ambient air pollution and prenatal and early childhood health effects. Eur J Epidemiol. 2005;20(2):183-99. PMid:15792286. http://dx.doi.org/10.1007/ s10654-004-3005-9

18. Medeiros A, Gouveia N. Relationship between low birthweight and air pollution in the city of Sao Paulo, Brazil [Article in Portuguese]. Rev Saude Publica. 2005;39(6):965-72. PMid:16341408. http:// dx.doi.org/10.1590/S0034-89102005000600015

19. Wu J, Ren C, Delfino RJ, Chung J, Wilhelm M, Ritz B. Association between local traffic-generated air pollution and preeclampsia and preterm delivery in the south coast air basin of California. Environ Health Perspect. 2009;117(11):1773-9. PMid:20049131 PMCid:2801174. http://dx.doi.org/10.1289/ehp.0800334

20. Shusterman D. The effects of air pollutants and irritants on the upper airway. Proc Am Thorac Soc. 2011;8(1):101-5. PMid:21364227. http://dx.doi. org/10.1513/pats.201003-027RN

21. Kelly FJ, Fussell JC. Air pollution and airway disease. Clin Exp Allergy. 2011;41(8):1059-71. PMid:21623970. http://dx.doi.org/10.1111/j.1365-2222.2011.03776.x

22. Chang YK, Wu CC, Lee LT, Lin RS, Yu YH, Chen YC. The short-term effects of air pollution on adolescent lung function in Taiwan. Chemosphere. 2012;87(1):26-30. PMid:22189374. http://dx.doi.org/10.1016/j. chemosphere.2011.11.048

23. McCreanor J, Cullinan P, Nieuwenhuijsen MJ, StewartEvans J, Malliarou E, Jarup L, et al. Respiratory effects of exposure to diesel traffic in persons with asthma. $\mathrm{N}$ Engl J Med. 2007;357(23):2348-58. PMid:18057337. http://dx.doi.org/10.1056/NEJMoa071535

24. Gauderman WJ, Avol E, Gilliland F, Vora H, Thomas $\mathrm{D}$, Berhane $\mathrm{K}$, et al. The effect of air pollution on lung development from 10 to 18 years of age. $\mathrm{N}$ Engl J Med. 2004;351(11):1057-67. Erratum in: N Engl J Med. 2005;352(12):1276. PMid:15356303. http://dx.doi. org/10.1056/NEJMoa040610

25. Gauderman WJ, Vora H, McConnell R, Berhane K, Gilliland F, Thomas D, et al. Effect of exposure to traffic on lung development from 10 to 18 years of age: a cohort study. Lancet. 2007;369(9561):571-7. http://dx.doi. org/10.1016/S0140-6736(07)60037-3

26. Schikowski T, Sugiri D, Ranft U, Gehring U, Heinrich J, Wichmann HE, et al. Long-term air pollution exposure and living close to busy roads are associated with COPD in women. Respir Res. 2005;6:152. PMid:16372913 PMCid:1352358. http://dx.doi. org/10.1186/1465-9921-6-152

27. Downs SH, Schindler C, Liu LJ, Keidel D, Bayer-Oglesby $\mathrm{L}$, Brutsche $\mathrm{MH}$, et al. Reduced exposure to PM10 and attenuated age-related decline in lung function. $\mathrm{N}$ Engl J Med. 2007;357(23):2338-47. PMid:18057336. http:// dx.doi.org/10.1056/NEJMoa073625

28. Watts J. Doctors blame air pollution for China's asthma increases. Lancet. 2006;368(9537):719-20. http://dx.doi. org/10.1016/S0140-6736(06)69267-2 
29. Samoli E, Nastos PT, Paliatsos AG, Katsouyanni K, Priftis KN. Acute effects of air pollution on pediatric asthma exacerbation: evidence of association and effect modification. Environ Res. 2011;111(3):418-24. PMid:21296347. http://dx.doi.org/10.1016/j. envres.2011.01.014

30. Iskandar A, Andersen ZJ, Bønnelykke K, Ellermann T, Andersen KK, Bisgaard H. Coarse and fine particles but not ultrafine particles in urban air trigger hospital admission for asthma in children. Thorax. 2012;67(3):252-7. PMid:22156960. http://dx.doi.org/10.1136/ thoraxjnl-2011-200324

31. Arbex MA, Martins LC, de Oliveira RC, Pereira LA, Arbex FF, Cançado JE, et al. Air pollution from biomass burning and asthma hospital admissions in a sugar cane plantation area in Brazil. J Epidemiol Community Health. 2007;61(5):395-400. PMid:17435205 PMCid:2465679. http://dx.doi.org/10.1136/ jech.2005.044743

32. Mascarenhas MD, Vieira LC, Lanzieri TM, Leal AP, Duarte AF, Hatch DL. Anthropogenic air pollution and respiratory disease-related emergency room visits in Rio Branco, Brazil--September, 2005. J Bras Pneumol. 2008;34(1):42-6. PMid:18278375. http:// dx.doi.org/10.1590/S1806-37132008000100008

33. Friedman MS, Powell KE, Hutwagner L, Graham LM, Teague WG. Impact of changes in transportation and commuting behaviors during the 1996 Summer Olympic Games in Atlanta on air quality and childhood asthma. JAMA. 2001;285(7):897-905. PMid:11180733. http:// dx.doi.org/10.1001/jama.285.7.897

34. Li Y, Wang W, Kan H, Xu X, Chen B. Air quality and outpatient visits for asthma in adults during the 2008 Summer Olympic Games in Beijing. Sci Total Environ. 2010;408(5):1226-7. PMid:19959207. http:// dx.doi.org/10.1016/j.scitotenv.2009.11.035

35. McConnell R, Berhane K, Gilliland F, London SJ, Islam T, Gauderman WJ, et al. Asthma in exercising children exposed to ozone: a cohort study. Lancet. 2002;359(9304):386-91. Erratum in: Lancet 2002;359(9309):896. http://dx.doi. org/10.1016/S0140-6736(02)07597-9

36. Gehring U, Wijga AH, Brauer M, Fischer P, de Jongste JC, Kerkhof M, et al. Traffic-related air pollution and the development of asthma and allergies during the first 8 years of life. Am J Respir Crit Care Med. 2010;181(6):596-603. PMid:19965811. http:// dx.doi.org/10.1164/rccm.200906-08580C

37. Morgenstern V, Zutavern A, Cyrys J, Brockow 1, Koletzko S, Krämer U, et al. Atopic diseases, allergic sensitization, and exposure to traffic-related air pollution in children. Am J Respir Crit Care Med. 2008;177(12):1331-7. PMid:18337595. http://dx.doi.org/10.1164/ rccm.200701-0360C

38. Künzli N, Bridevaux PO, Liu LJ, Garcia-Esteban R, Schindler C, Gerbase MW, et al. Traffic-related air pollution correlates with adult-onset asthma among never-smokers. Thorax. 2009;64(8):664-70. PMid:19359271. http:// dx.doi.org/10.1136/thx.2008.110031

39. Ko FW, Hui DS. Air pollution and chronic obstructive pulmonary disease. Respirology. 2012;17(3):395-401. PMid:22142380. $\operatorname{org} / 10.1111 / \mathrm{j} .1440-1843.2011 .02112 . x$

40. Ko FW, Tam W, Wong TW, Chan DP, Tung AH, Lai CK, et al. Temporal relationship between air pollutants and hospital admissions for chronic obstructive pulmonary disease in Hong Kong. Thorax. 2007;62(9):780-5. PMid:17311838 PMCid:2117326. http://dx.doi.org/10.1136/ thx.2006.076166

41. Medina-Ramón M, Zanobetti A, Schwartz J. The effect of ozone and PM10 on hospital admissions for pneumonia and chronic obstructive pulmonary disease: a national multicity study. Am J Epidemiol. 2006;163(6):579-88. PMid:16443803. http://dx.doi.org/10.1093/aje/kwj078

42. Arbex MA, de Souza Conceição GM, Cendon SP, Arbex FF, Lopes AC, Moysés EP, et al. Urban air pollution and chronic obstructive pulmonary disease-related emergency department visits. J Epidemiol Community Health. 2009;63(10):777-83. PMid:19468016. http:// dx.doi.org/10.1136/jech.2008.078360

43. Andersen ZJ, Hvidberg M, Jensen SS, Ketzel M, Loft $\mathrm{S}$, Sørensen M, et al. Chronic obstructive pulmonary disease and long-term exposure to traffic-related air pollution: a cohort study. Am J Respir Crit Care Med. 2011;183(4):455-61. PMid:20870755. http://dx.doi. org/10.1164/rccm.201006-09370C

44. Hu G, Zhou Y, Tian J, Yao W, Li J, Li B, et al. Risk of COPD from exposure to biomass smoke: a metaanalysis. Chest. 2010;138(1):20-31. PMid:20139228.

45. Kurmi OP, Semple S, Simkhada P, Smith WC, Ayres JG. COPD and chronic bronchitis risk of indoor air pollution from solid fuel: a systematic review and meta-analysis. Thorax. 2010;65(3):221-8. PMid:20335290. http:// dx.doi.org/10.1136/thx.2009.124644

46. Kodgule R, Salvi S. Exposure to biomass smoke as a cause for airway disease in women and children. Curr Opin Allergy Clin Immunol. 2012;12(1):82-90. PMid:22157154. http://dx.doi.org/10.1097/ACl.0b013e32834ecb65

47. Dherani M, Pope D, Mascarenhas M, Smith KR, Weber $\mathrm{M}$, Bruce N. Indoor air pollution from unprocessed solid fuel use and pneumonia risk in children aged under five years: a systematic review and meta-analysis. Bull World Health Organ. 2008;86(5):390-398C. PMid:18545742 PMCid:2647443. http://dx.doi.org/10.2471/BLT.07.044529

48. Host S, Larrieu S, Pascal L, Blanchard M, Declercq C, Fabre P, et al. Short-term associations between fine and coarse particles and hospital admissions for cardiorespiratory diseases in six French cities. Occup Environ Med. 2008;65(8):544-51. PMid:18056749. http://dx.doi.org/10.1136/oem.2007.036194

49. Belleudi V, Faustini A, Stafoggia M, Cattani G, Marconi A, Perucci CA, et al. Impact of fine and ultrafine particles on emergency hospital admissions for cardiac and respiratory diseases. Epidemiology. 2010;21(3):414-23. PMid:20386174. http://dx.doi.org/10.1097/ EDE.0b013e3181d5c021

50. Neupane B, Jerrett M, Burnett RT, Marrie T, Arain A, Loeb M. Long-term exposure to ambient air pollution and risk of hospitalization with community-acquired pneumonia in older adults. Am J Respir Crit Care Med. 2010;181(1):47-53. PMid:19797763. http://dx.doi. org/10.1164/rccm.200901-01600C

51. Pope CA 3rd, Burnett RT, Thurston GD, Thun MJ, Calle EE, Krewski D, et al. Cardiovascular mortality and long-term exposure to particulate air pollution: epidemiological evidence of general pathophysiological pathways of disease. Circulation. 2004;109(1):71-7. PMid:14676145. http://dx.doi.org/10.1161/01.CIR.0000108927.80044.7F

52. Jemal A, Bray F, Center MM, Ferlay J, Ward E, Forman D. Global cancer statistics. CA Cancer J Clin. 2011;61(2):69-90. 
Erratum in: CA Cancer J Clin. 2011;61(2):134. PMid:21296855. http://dx.doi.org/10.3322/caac.20107

53. Yang W, Omaye ST. Air pollutants, oxidative stress and human health. Mutat Res. 2009;674(1-2):45-54. PMid:19013537. http://dx.doi.org/10.1016/j. mrgentox.2008.10.005

54. Pope CA 3rd, Burnett RT, Thun MJ, Calle EE, Krewski $\mathrm{D}$, Ito $\mathrm{K}$, et al. Lung cancer, cardiopulmonary mortality, and long-term exposure to fine particulate air pollution. JAMA. 2002;287(9):1132-41. http://dx.doi.org/10.1001/ jama.287.9.1132

55. Vineis P, Hoek G, Krzyzanowski M, Vigna-Taglianti F, Veglia F, Airoldi L, et al. Lung cancers attributable to environmental tobacco smoke and air pollution in non-smokers in different European countries: a prospective study. Environ Health. 2007;6:7. PMid:17302981 PMCid:1803768. http://dx.doi.org/10.1186/1476-069X-6-7

56. Laden F, Schwartz J, Speizer FE, Dockery DW. Reduction in fine particulate air pollution and mortality: Extended follow-up of the Harvard Six Cities study. Am J Respir
Crit Care Med. 2006;173(6):667-72. PMid:16424447 PMCid:2662950. http://dx.doi.org/10.1164/ rccm.200503-4430C

57. Pope CA 3rd. Mortality effects of longer term exposures to fine particulate air pollution: review of recent epidemiological evidence. Inhal Toxicol. 2007;19 Suppl 1:33-8. PMid:17886048. http://dx.doi. org/10.1080/08958370701492961

58. Carlisle AJ, Sharp NC. Exercise and outdoor ambient air pollution. Br J Sports Med. 2001;35(4):214-22. http:// dx.doi.org/10.1136/bjsm.35.4.214

59. Daigle CC, Chalupa DC, Gibb FR, Morrow PE, Oberdörster G, Utell MJ, et al. Ultrafine particle deposition in humans during rest and exercise. Inhal Toxicol. 2003;15(6):539-52. PMid:12692730. http:// dx.doi.org/10.1080/08958370304468

60. Rundell KW. Effect of air pollution on athlete health and performance. Br J Sports Med. 2012;46(6):407-12. PMid:22267572. http://dx.doi.org/10.1136/ bjsports-2011-090823

\section{About the authors}

\section{Marcos Abdo Arbex}

Senior Researcher. Center for Environmental Epidemiology Studies, Air Pollution Laboratory, Department of Pathology, University of São Paulo School of Medicine, São Paulo, Brazil; and Professor of Pulmonology. Centro Universitário de Araraquara - Uniara, Araraquara University Center - School of Medicine, Araraquara, Brazil.

\section{Ubiratan de Paula Santos}

Senior Researcher. Center for Environmental Epidemiology Studies, Air Pollution Laboratory, Department of Pathology, University of São Paulo School of Medicine, São Paulo, Brazil.

\section{Lourdes Conceição Martins}

Senior Researcher. Center for Environmental Epidemiology Studies, Air Pollution Laboratory, Department of Pathology, University of São Paulo School of Medicine, São Paulo, Brazil; and Assistant Professor. Graduate Program in Public Health, Universidade Católica de Santos - UNISANTOS, Catholic University of Santos - Santos, Brazil.

\section{Paulo Hilário Nascimento Saldiva}

Full Professor. Department of Pathology, University of São Paulo School of Medicine, São Paulo, Brazil.

\section{Luiz Alberto Amador Pereira}

Senior Researcher. Center for Environmental Epidemiology Studies, Air Pollution Laboratory, Department of Pathology, University of São Paulo School of Medicine, São Paulo, Brazil; and Assistant Professor. Graduate Program in Public Health, Universidade Católica de Santos - UNISANTOS, Catholic University of Santos - Santos, Brazil.

\section{Alfésio Luis Ferreira Braga}

Senior Researcher. Center for Environmental Epidemiology Studies, Air Pollution Laboratory, Department of Pathology, University of São Paulo School of Medicine, São Paulo, Brazil; and Assistant Professor. Graduate Program in Public Health, Universidade Católica de Santos - UNISANTOS, Catholic University of Santos - Santos, Brazil. 